\title{
Raised urinary glucocorticoid and adrenal androgen precursors in the urine of young hypertensive patients: possible evidence for partial glucocorticoid resistance
}

\author{
W Shamim, M Yousufuddin, D P Francis, P Gualdiero, J W Honour, S D Anker, \\ A J S Coats
}

\begin{abstract}
Objective-To evaluate urinary glucocorticoid excretion profiles in a cohort of recently diagnosed young hypertensive patients.

Methods-After excluding patients with secondary causes, 60 individuals with premature hypertension were recruited (diagnosed by ambulatory blood pressure monitoring before the age of 36 years). In addition, 30 older hypertensive controls (age of onset $>36$ years, "middle aged hypertensive controls"), and 30 normal controls (age matched to the young hypertensive group) were studied. All provided 24 hour urine collections for mass spectrometry for total cortisol metabolites and total androgen metabolites by gas chromatography.

Results-Among male patients, those with premature hypertension had higher total urinary excretion of cortisol metabolites (mean (SD), $13332(6472) \mu \mathrm{g} /$ day) than age matched normal controls $(7270(1788) \mu \mathrm{g} /$ day; $\mathrm{p}=0.00001)$ or middle aged hypertensive controls (8315 (3565) $\mu \mathrm{g} / \mathrm{day} ; \mathrm{p}=0.002)$. A similar increase was seen among the female patients, although the absolute concentrations were lower. There was no significant difference between middle aged hypertensive patients and normal controls. Urinary total androgen excretion profiles in female patients also showed an unusual increase in the premature hypertension group (2958 (1672) $\mu \mathrm{g} /$ day) compared with the other groups (middle aged hypertensive controls, 1373 (748) $\mu \mathrm{g} / \mathrm{day}$, $\mathrm{p}=0.0003$; normal controls, $1687(636) \mu \mathrm{g} /$ day, $\mathrm{p}=0.002)$. In all subjects, serum sodium and creatinine concentrations were within the normal range; serum potassium concentrations were found to be low before the start of treatment.

Conclusions-Individuals presenting with premature hypertension have an abnormally high excretion of glucocorticoid metabolites in the urine. While the mechanism remains uncertain, these findings are compatible with partial resistance of the glucocorticoid receptors, with a compensatory increase in cortisol and androgen metabolites. The mineralocorticoid effects of the latter (sodium and water retention) may contribute to an abnormally high blood pressure and may have implications for targeted selection of first line treatment in young hypertensive patients. (Heart 2001;86:139-144)
\end{abstract}

Keywords: premature hypertension; glucocorticoid resistance; cortisol metabolites; glucocorticoid receptor resistance

Hypertension is common worldwide and confers an increased risk of stroke, myocardial infarction, and renal failure. It may affect half the population over the age of 60 in developed countries. ${ }^{1}$ In only a small minority of cases is a clear cause found, such as chronic renal disease $(2 \%)$, renovascular disease $(2 \%)$, primary aldosteronism (1\%), Cushing's syndrome $(0.5 \%)$, phaeochromocytoma $(0.2 \%)$, oral contraceptives $(0.2 \%)$, and coarctation of the aorta $(0.2 \%) .^{2-4}$ The vast majority of patients are therefore given the diagnosis of essential hypertension.

Among hypertensive patients referred to specialist centres, $10 \%$ are referred for refractory hypertension and there is increased representation of young patients. ${ }^{5}$ Results of the Four corner study hinted that abnormalities of cortisol metabolites may have particular importance in hypertension in young patients. ${ }^{6}$

Glucocorticoids are important in maintaining vital haemodynamic mechanisms in the body. Cortisol has mineralocorticoid-like effects $^{7-11}$ and may have a role in the regulation of systemic arterial blood pressure. It could be involved in the pathogenesis of hypertension, as previously suggested by studies on humans ${ }^{12-15}$ and animals. ${ }^{12}{ }^{16}$ Some abnormalities of cortisol metabolism are well recognised (for example, Cushing's disease) but there are other less well known conditions where glucocorticoid abnormalities can cause hypertension. ${ }^{17-19}$ Milder abnormalities of glucocorticoid production and excretion rates may be more common in hypertensive subjects, particularly those who present when they are young. Our aim in this

Table 1 Antihypertensive drug treatment in the hypertensive groups

\begin{tabular}{lrr}
\hline Drug treatment & $\begin{array}{l}\text { Premature } \\
\text { hypertension }\end{array}$ & \multicolumn{1}{c}{$\begin{array}{l}\text { Hypertensive } \\
\text { controls }\end{array}$} \\
\hline$\beta$ Blocker & $26(43 \%)$ & $14(46 \%)$ \\
Diuretics & $12(20 \%)$ & $9(30 \%)$ \\
Calcium channel blocker & $32(53 \%)$ & $13(43 \%)$ \\
ACE inhibitors & $41(68 \%)$ & $22(73 \%)$ \\
Angiotensin II receptor blockers & $22(36 \%)$ & $15(50 \%)$ \\
$\alpha$ Blocker & $8(13 \%)$ & $5(16 \%)$ \\
\hline
\end{tabular}

Values are numbers of patients taking a particular drug (\% of total number of patients)

ACE, angiotensin converting enzyme. 
Table 2 Patient characteristics

\begin{tabular}{|c|c|c|c|c|c|}
\hline & Normal controls & $p$ Value $(A)$ & $\begin{array}{l}\text { Premature } \\
\text { hypertensive }\end{array}$ & $p$ Value (B) & $\begin{array}{l}\text { Middle aged } \\
\text { hypertensive }\end{array}$ \\
\hline \multicolumn{6}{|l|}{ Male subjects } \\
\hline Age (years) & $31.1(4.0)$ & 0.07 & $35.5(10.4)$ & 0.02 & $46.4(7.0)$ \\
\hline Age at presentation (years) & & & $28.0(7.1)$ & $<0.0001$ & $42.5(4.8)$ \\
\hline $\mathrm{n}$ & 14 & & 34 & & 17 \\
\hline BMI $\left(\mathrm{kg} / \mathrm{m}^{2}\right)$ & $25.0(1.2)$ & 0.2 & $25.6(3.4)$ & 0.85 & $25.9(2.8)$ \\
\hline Heart rate (beats/min) & $76(4)$ & 0.65 & $77(6)$ & 0.9 & $77(19)$ \\
\hline Systolic BP (clinic) & 124 & $<0.0001$ & 158 & 0.004 & 181 \\
\hline Diastolic BP (clinic) & 76 & 0.002 & 98 & 0.03 & 112 \\
\hline $\mathrm{Hb}(\mathrm{g} / \mathrm{dl})$ & $14.4(0.5)$ & 0.92 & $14.4(0.6)$ & 0.35 & $14.0(0.6)$ \\
\hline \multicolumn{6}{|l|}{ Female subjects } \\
\hline Age (years) & $30.5(3.9)$ & 0.1 & $32.3(7.5)$ & $<0.0001$ & $51.8(7.8)$ \\
\hline Age at presentation (years) & & & $27.5(5.6)$ & $<0.0001$ & $48.2(8.0)$ \\
\hline $\mathrm{n}$ & 16 & & 26 & & 13 \\
\hline $\mathrm{BMI}\left(\mathrm{kg} / \mathrm{m}^{2}\right)$ & $26.7(6.2)$ & 0.7 & $27.3(5.4)$ & 0.34 & $30.7(8.0)$ \\
\hline Heart rate (beats/min) & $76(6)$ & 0.53 & $78(7)$ & 0.62 & $79(4)$ \\
\hline Systolic BP (clinic) & 118 & 0.003 & 146 & 0.29 & 158 \\
\hline Diastolic BP (clinic) & 78 & 0.0001 & 96 & 0.84 & 96 \\
\hline $\mathrm{Hb}(\mathrm{g} / \mathrm{dl})$ & $13.7(1.1)$ & 0.16 & $13.3(0.4)$ & 0.09 & $12.1(1.7)$ \\
\hline
\end{tabular}

Values are mean (SD).

(A), p value between normal controls and premature hypertensive patients; (B), $p$ value between premature hypertensive and middle aged hypertensive patients.

$\mathrm{BMI}$, body mass index; $\mathrm{BP}$, blood pressure; $\mathrm{Hb}$, haemoglobin.

study was to examine the adrenal steroid component in patients presenting with hypertension at an unusually young age.

\section{Methods}

PATIENTS AND STUDY DESIGN

We recruited 60 consecutive young hypertensive patients referred to our hypertension clinic. We also recruited 30 older hypertensive controls. The premature hypertension group was defined as patients who presented before the age of 36 years (mean (SD) age, 28.0 (7.1) years; range 19-36 years), while those presenting at an older age were described as the middle aged hypertensive group (mean age 42.5 (4.8) years, range 37-52 years). Another group of 30 normal young controls of less than 36 years (age matched to the premature hypertension group) were also recruited (mean age 31.1 (4.0) years, range 23-38 years). There were 60 premature hypertensive patients, 30 normal controls, and 30 middle aged hypertensive patients.

Patients were considered to be hypertensive when their blood pressure was found to be above $140 / 90 \mathrm{~mm} \mathrm{Hg}$ on at least three clinical readings, and later confirmed by ambulatory blood pressure monitoring.
We analysed male and female groups separately because of the sex differences in levels of excretion of cortisol. ${ }^{20}{ }^{21}$

All patients underwent routine clinical examination and investigation, including biochemistry, ECG, chest $x$ ray, and 24 hour ambulatory blood pressure monitoring. Twenty four hour ambulatory monitoring in patients with suspected hypertension provides accurate and reproducible values of blood pressure, and the average blood pressure measurements thus derived correlate better with target organ damage than single or multiple clinic measurements. ${ }^{22-29}$ Ambulatory blood pressure monitoring was performed using previously validated monitors and processors (TM 2420-2020, A\&D company, Tokyo, Japan). ${ }^{30}$ Blood pressure measurements were taken every 15 minutes during the daytime and every 30 minutes during sleep. During the monitoring period patients were instructed to perform their normal daily routine activities.

Echocardiography, ultrasound of the kidneys, urography, iodine-123 metaiodobenzylguanidine (MIBG) scanning, captopril renal scan, computed tomography, and

Table 3 Results of endocrine, blood pressure, and renal investigations in the three groups

\begin{tabular}{|c|c|c|c|c|c|}
\hline & Normal controls & $p$ Value $(A)$ & $\begin{array}{l}\text { Premature } \\
\text { hypertensive }\end{array}$ & $p$ Value (B) & $\begin{array}{l}\text { Middle aged } \\
\text { hypertensive }\end{array}$ \\
\hline \multicolumn{6}{|l|}{ Male patients } \\
\hline Cortisol metabolites ( $\mu \mathrm{g} /$ day) & $7270(1788)$ & 0.0001 & $13332(6472)$ & 0.002 & $8315(3565)$ \\
\hline Androgen metabolites $(\mu \mathrm{g} /$ day $)$ & $2783(750)$ & 0.2 & $3801(2015)$ & 0.03 & $2392(1373)$ \\
\hline ABPM 24 h systolic $(\mathrm{mm} \mathrm{Hg})$ & 116.2 & $<0.0001$ & 147.5 & 0.27 & 158.9 \\
\hline ABPM 24 h diastolic $(\mathrm{mm} \mathrm{Hg})$ & 73.8 & 0.005 & 89.3 & 0.45 & 95.2 \\
\hline $24 \mathrm{~h}$ urinary sodium ( $\mathrm{mmol})$ & $147(32)$ & & $124(26)$ & & $167(57)$ \\
\hline $24 \mathrm{~h}$ urinary potassium (mmol) & $69(27)$ & & $88(14)$ & & $72(22)$ \\
\hline $24 \mathrm{~h}$ urine volume $(\mathrm{ml})$ & $1746(466)$ & & $1792(629)$ & & $1668(280)$ \\
\hline \multicolumn{6}{|l|}{ Female patients } \\
\hline Cortisol metabolites ( $\mu \mathrm{g} /$ day) & $4588(1480)$ & $<0.0001$ & $11016(4261)$ & 0.02 & $7613(2507)$ \\
\hline Androgen metabolites ( $\mu \mathrm{g} /$ day) & $1687(636)$ & 0.002 & $2958(1672)$ & 0.0003 & $1373(748)$ \\
\hline ABPM 24 h systolic $(\mathrm{mm} \mathrm{Hg})$ & 113.4 & 0.0002 & 148 & 0.52 & 142.5 \\
\hline ABPM 24 h diastolic ( $\mathrm{mm} \mathrm{Hg}$ ) & 70.7 & $<0.0001$ & 98.7 & 0.1 & 85 \\
\hline $24 \mathrm{~h}$ urinary sodium (mmol) & $142(44)$ & & $132(36)$ & & $148(45)$ \\
\hline $24 \mathrm{~h}$ urinary potassium $(\mathrm{mmol})$ & $76(21)$ & & $87(18)$ & & $75(15)$ \\
\hline $24 \mathrm{~h}$ urine volume $(\mathrm{ml})$ & $1702(842)$ & & $1640(603)$ & & $1689(889)$ \\
\hline
\end{tabular}

Values are mean $(\mathrm{SD})$

(A), $p$ value between normal controls and premature hypertensive patients; (B), $p$ value between premature hypertensive and middle aged hypertensive patients.

ABPM, ambulatory blood pressure monitoring. 


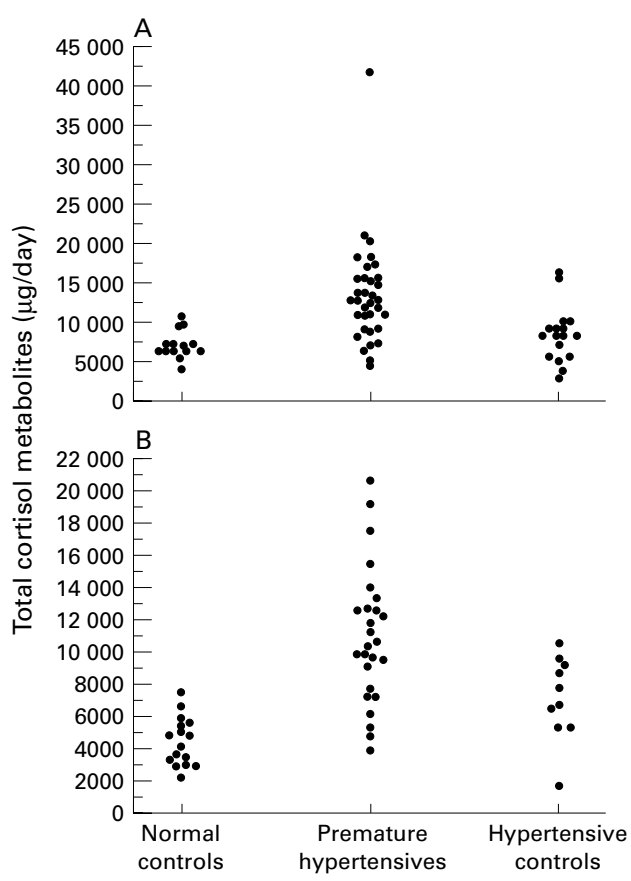

Figure 1 Twenty four hour urinary excretion of total cortisol metabolites in $(A)$ male and $(B)$ female patients.

magnetic resonance imaging of the adrenal glands, and estimation of 24 hour catecholamines were performed when clinically indicated.

Drug treatment in the hypertensive patients at the time of the investigation is summarised in table 1 .

After excluding the patients with secondary hypertension, 24 hour urine was collected by all the patients in non-acid bottles to measure total cortisol and androgen metabolite excretion rates. Twenty four hour urinary cortisol measurements were performed by a gas chromatographic method, ${ }^{31}$ using a HewlettPackard gas chromatograph (5890 series II; Hewlett-Packard Inc, Andover, Massachusetts, USA), attached to a Hewlett-Packard mass selective detector.

The validity and reproducibility of the methods of measurements of 24 hour urinary cortisol metabolites have previously been demonstrated by our group. ${ }^{32}$ The coefficients of variation for cortisol metabolites in this study ${ }^{31}$ were from $2.4 \%$ to $16.6 \%$ (important metabolites-for example, androsterone, aetiocholanolone, dehydroepiandrosterone (DHA), and $\beta$-allo-tetrahydrocortisol-showed higher reproducibility). During the 24 hour ambulatory blood pressure monitoring and the 24 hour urine collection, and for 12 hours before, patients were asked to refrain from consuming excessive amounts of alcohol, tea or coffee.

\section{STATISTICAL ANALYSIS}

The data are presented as mean (SD). The results of individual values for total urinary cortisol metabolite and total urinary androgen metabolite excretion were considered abnormal if the values were greater than $2 \mathrm{SD}$ above the mean of the normal controls. We used the Kruskal-Wallis non-parametric test to compare the three groups and the Mann-Whitney

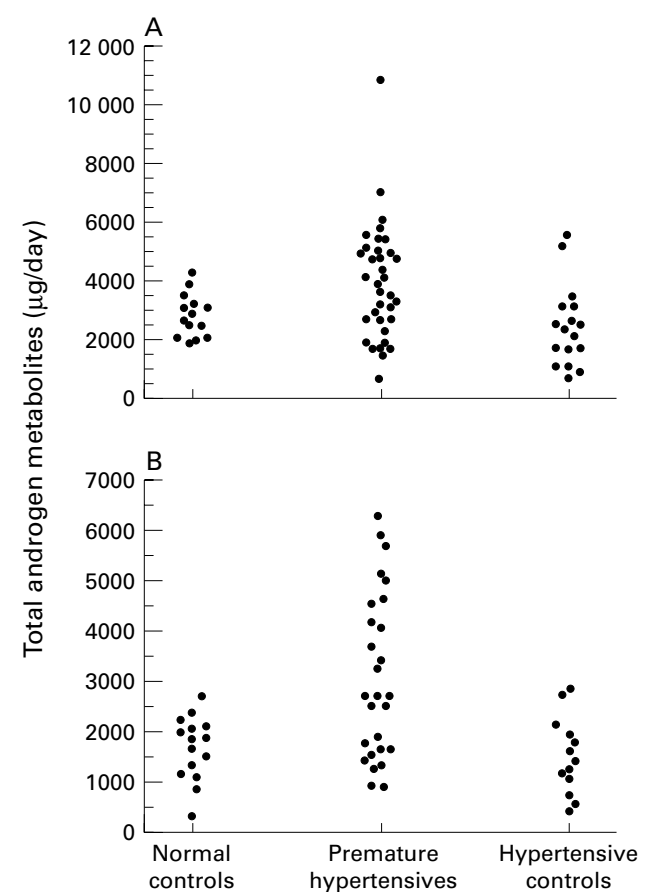

Figure 2 Twenty four hour urinary excretion of total androgen metabolites in $(A)$ male and $(B)$ female patients.

$\mathrm{U}$ test to assess the differences between two groups. Probability values of $\mathrm{p}<0.05$ were considered significant. Statistical analysis was performed using Statview 5.0 for Windows (Abacus Concepts, USA).

\section{Results}

There was no significant difference between three groups in body mass index (BMI), heart rate, or haemoglobin (table 2). The values for serum sodium and creatinine were within normal limits in all three groups. Serum potassium in the premature hypertension group was found to be significantly lower (mean (SD) 2.9 $(0.8) \mathrm{mmol} / \mathrm{l}, \mathrm{p}=0.001)$ than in the other two groups. The premature hypertensive patients tended to have slightly lower blood pressure than the middle aged hypertensive patients, whether determined by 24 hour ambulatory blood pressure monitoring (table 3 ) or by clinic blood pressure (table 2).

\section{TOTAL CORTISOL METABOLITES}

The differences in total urinary cortisol metabolite excretion were highly significant $(\mathrm{p}<0.0001)$ between the three groups in both male and female patients. Total urinary cortisol metabolites in the male subjects were substantially higher in premature hypertensive patients $(13332 \mu \mathrm{g} /$ day $)$ than in the middle aged hypertensive controls $(8315 \mu \mathrm{g} /$ day, $\mathrm{p}=0.002)$ or the normal controls $(7270 \mu \mathrm{g} /$ day, $\mathrm{p}=0.0001)$, as shown in fig $1 \mathrm{~A}$. In the female subjects there was an increase in urinary cortisol in the group with premature hypertension compared with the middle aged and young control groups (as shown in table 3 and fig 1B). Approximately two thirds of the male and female patients with premature hypertension had abnormally high urinary cortisol concentrations compared with the age matched 


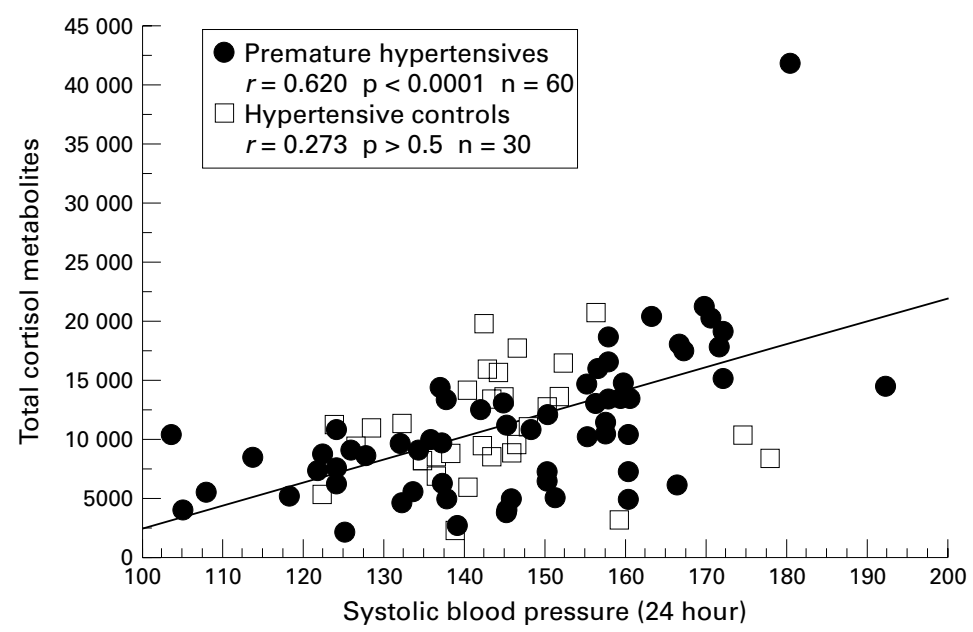

Figure 3 Regression analysis between total cortisol metabolites and systolic blood pressure in patients with premature hypertension and hypertensive controls.

normal controls (male patients $65 \%$ v $0 \%$, $\mathrm{p}=0.001 ;$ female patients $68 \%$ v $0 \%$, $\mathrm{p}=0.0008)$, or with the middle aged hypertensive group (male patients $65 \%$ v $0 \%$, $\mathrm{p}=0.002 ;$ female patients $65 \%$ v $20 \%$, $\mathrm{p}=0.02)$.

TOTAL ANDROGEN METABOLITES

In contrast to the male patients, among the female patients there was a significant difference in total urinary androgen metabolite excretion among the three groups $(p=0.001)$. In female patients, the total urinary androgen metabolite excretion was higher in the premature hypertensive group $(2958 \mu \mathrm{g} /$ day $)$ than in the middle aged hypertensive group $(1373 \mu \mathrm{g} /$ day; $\mathrm{p}=0.0003)$ or in the normal controls $(1687 \mu \mathrm{g} /$ day; $\mathrm{p}=0.002$ ), as shown in table 3 and fig $2 \mathrm{~B}$. In male patients, total urinary androgen metabolite concentrations were similar in the premature hypertension group and the young normal subjects $(p=0.2)$. However, there was a significant difference when the premature hypertensive patients were compared with the middle aged hypertensive patients $(p=0.03)$, as shown in fig 2A. Approximately one third of male patients and two thirds of female patients with premature hypertension had abnormally high urinary androgen concentrations compared with their male and female counterparts, both in the young control group (male patients $34 \% v$ $0 \%, \mathrm{p}=0.07$; female patients $63 \%$ v $0 \%$, $\mathrm{p}=0.002)$ and in the middle aged hypertensive group (male patients $34 \%$ v $12.5 \%, \mathrm{p}=0.38$; female patients $63 \% v 10 \%, \mathrm{p}=0.008$ ).

CORRELATIONS

The correlations between systolic blood pressure and the urinary excretion of total cortisol metabolites and androgen metabolites in premature hypertensive patients, hypertensive controls, and normal controls are shown in table 4 and fig 3. A significant correlation was found between total cortisol metabolites and total androgen metabolites in the premature hypertension group (male patients $r=0.499$, $\mathrm{p}=0.009 ; \quad$ female patients $r=0.388$, $\mathrm{p}=0.500)$, but not in the hypertensive controls $(\mathrm{p}>0.5)$.

\section{Discussion}

In this study we found a significantly higher urinary excretion of total cortisol metabolites in individuals with premature hypertension than in normal individuals of similar age, or in patients with hypertension presenting at a later age but with similar body size. These increased cortisol metabolite excretion rates were seen in both male and female subjects and occurred in more than half the patients in the premature hypertension group. The results were found to be essentially identical when also analysed by parametric methods.

In the urine steroid analyses none of our patients had evidence of corticosterone or deoxycorticosterone secreting tumours, biosynthetic defects (such as 17-hydroxylase or 11-hydroxylase deficiency), mineralocorticoid excess syndrome, or dexamethasone suppressible hyperaldosteronism (table 5). ${ }^{33-38}$ There was no difference in weight nor was there any concomitant pathology that might explain the differences in urinary excretion of glucocorticoid metabolites. While we have not controlled for lifestyle and psychological "stress," the urine collections were obtained under home conditions, and experiences from ambulatory blood pressure monitoring suggest that this avoids an alerting response in most individuals.

Of the various pathogenic mechanisms involved in the development of hypertension, three that are important in rare familial cases have recently received special attention because they may be relevant to milder forms of essential hypertension. These are glucocorticoid remediable hyperaldosteronism, hypertension with variations in angiotensin converting enzyme activity, and Liddle's syndrome. ${ }^{39-46}$ Increased urinary excretion of glucocorticoid metabolites in young hypertensive patients, ${ }^{47}$ in the absence of any other clinical or laboratory stigmata of secondary hypertension, is likely to reflect differences in glucocorticoid production. One possible underlying mechanism is a partial resistance of glucocorticoid receptors to cortisol. Normally cortisol and androgens have different affinities for two different types of

Table 4 Correlations between total urinary steroid metabolites and systolic and diastolic blood pressure

\begin{tabular}{|c|c|c|c|}
\hline & Premature hypertensive & Middle aged hypertensive & Normal control \\
\hline $\begin{array}{l}\text { Total urinary cortisol metabolites } v \text { : } \\
\text { Systolic blood pressure }(24 \mathrm{~h}) \\
\text { Diastolic blood pressure }(24 \mathrm{~h})\end{array}$ & $\begin{array}{l}r=0.620, \mathrm{p}<0.0001 \\
r=0.162, \mathrm{p}=0.2\end{array}$ & $\begin{array}{l}r=0.273, \mathrm{p}>0.5 \\
r=0.013, \mathrm{p}=0.9\end{array}$ & $\begin{array}{l}r=0.271, \mathrm{p}=0.14 \\
r=0.039, \mathrm{p}=0.8\end{array}$ \\
\hline $\begin{array}{l}\text { Total urinary androgen metabolites } v \text { : } \\
\text { Systolic blood pressure }(24 \mathrm{~h}) \\
\text { Diastolic blood pressure }(24 \mathrm{~h})\end{array}$ & $\begin{array}{l}r=0.350, \mathrm{p}=0.01 \\
r=0.040, \mathrm{p}=0.7\end{array}$ & $\begin{array}{l}r=0.297, \mathrm{p}=0.1 \\
r=0.281, \mathrm{p}=0.1\end{array}$ & $\begin{array}{l}r=0.178, \mathrm{p}=0.3 \\
r=-0.151, \mathrm{p}=0.4\end{array}$ \\
\hline
\end{tabular}


Table 5 Other conditions with glucocorticoid metabolite abnormalities

\begin{tabular}{|c|c|}
\hline Condition & Metabolic abnormality \\
\hline \multicolumn{2}{|l|}{ Tumours } \\
\hline Corticosterone secreting tumours & High concentrations of corticosterone \\
\hline Deoxycorticosterone secreting tumours & High concentrations of deoxycorticosterone $\mathrm{e}^{33}$ \\
\hline \multicolumn{2}{|l|}{ Biosynthetic defects } \\
\hline 17-Hydroxylase deficiency & $\begin{array}{l}\text { High ratio of THF }+\alpha \mathrm{THF} / \mathrm{THE} \text {; low } \\
\text { 17-hydroxycorticosterone concentrations }\end{array}$ \\
\hline 11-Hydroxylase deficiency & Little or no cortisol excretion ${ }^{35}$ \\
\hline \multicolumn{2}{|l|}{ Other conditions } \\
\hline Cushing's disease & $\begin{array}{l}\text { High serum cortisol levels; high excretion of urinary } \\
\text { free } \text { cortisol }^{36}\end{array}$ \\
\hline Mineralocorticoid excess syndrome & $\begin{array}{l}\text { F:E ratio increased (cortisol to cortisone ratio } \\
\text { increased) }\end{array}$ \\
\hline $\begin{array}{l}\text { Dexamethasone suppressible } \\
\text { hyperaldosteronism }\end{array}$ & $\begin{array}{l}\text { High urinary excretion of 18-hydroxycortisol } \\
\text { metabolites }^{38}\end{array}$ \\
\hline Partial glucocorticoid resistance & Total cortisol metabolites are increased \\
\hline
\end{tabular}

F:E ratio, cortisol to cortisone ratio; THE, tetrahydrocortisone; THF, tetrahydrocortisol.

glucocorticoid receptor. With receptor resistance, feedback inhibition of the hypothalamicpituitary axis is less effective, leading to an increased production of adrenocorticotrophic hormone which in turn causes an increased production and excessive excretion of glucocorticoid metabolites. Many of these glucocorticoid metabolites have mineralocorticoid-like effects, leading to an increased retention of sodium and water in the body. ${ }^{14}{ }^{15} 48-50$

Androgen metabolite excretion rates were abnormally high in female patients with premature hypertension, but in the male patients such a clear difference was not seen. It is possible that any tendency for premature hypertension to be associated with high androgen concentrations is masked by the higher background concentrations in male subjects.

Complete glucocorticoid receptor resistance is incompatible with life, because glucocorticoids have an important role in maintaining and regulating several vital mechanisms..$^{51-53}$ Partial glucocorticoid resistance, however, can occur $^{15} 50$ and is a familial disease with clinical manifestations that may include high serum cortisol concentrations, increased 24 hour urinary free cortisol, hypertension, hypokalaemia, hirsutism, and fatigue. In a study of 33 blood relatives of an index father and son with partial glucocorticoid resistance, nine of 33 had hypertension. In another study of six patients with partial glucocorticoid resistance and increased circulating concentrations of cortisol and deoxycortisol, one was hypertensive at the age of 36 . In the present study we evaluated 45 hypertensive patients under the age of 36 years and found that $65 \%$ of them had partial glucocorticoid resistance syndrome, with increased urinary excretion of cortisol metabolites.

CONCLUSIONS

We have identified a subset of young hypertensive patients with increased excretion of glucocorticoid metabolites in urine. This subset of individuals with premature hypertension may comprise a significant proportion of the young hypertensive population presenting to a tertiary hypertension clinic. We propose a syndrome of premature hypertension with increased urinary excretion of glucocorticoid metabolites, perhaps representing the effects of mild partial glucocorticoid resistance. This study was presented as an abstract at the British Society of
Cardiology in 2000 .

1 Burt VL, Whelton P, Roccella EJ, et al. Prevalence of hypertension in the US adult population: results from the Third National Health and Nutrition Examination Survey, 19881991. Hypertension 1995;25:305-13.

2 1991. Hypertension 1995;25:305-13. hypertension in a blood pressure clinic. Arch Intern Med 1987;147:1289-93.

3 Rudnick KV, Sackett DL, Hirst S, et al. Hypertension in family practice. Can Med Assoc F 1977;117:492-7.

4 Anderson GH, Blakeman N, Streeten DH. The effect of age on prevalence of secondary forms of hypertension in a blood pressure clinic. $\mathcal{F}$ Hypertens 1994;12:609-15.

5 Setaro JF, Black HR. Refractory hypertension. N Engl F Med 1992;327:543-7.

6 Watt GC, Harrap SB, Foy CG, et al. Abnormalities of glucocorticoid metabolism and the renin-angiosystem: a our-corner approach to the identification of genetic deter-

minants of blood pressure. F Hypertens 1992;10:473-82. ated with centrally administered aldosterone in dogs. ated with centrally administer

8 Gomez-Sanchez EP. Intracerebroventricular infusion of aldosterone induces hypertension in rats. Endocrinology 1986;118:819-23.

9 van den Berg D, de Kloet ER, van Dijken HH, et al. Differential central effects of mineralocorticoid, and glucocorticoid agonists and antagonists on blood pressure. Endo-
crinology 1990;126:118-24.

10 de Kloet ER, van den Berg D, van Dijken HH, et al. Brain corticosteroid receptors and central cardiovascular control. In: Mantero F, Takeda R, Scoggins BA, et al, eds. The adrenal and hypertension: from cloning to clinic. New York: Raven Press, 1989:121-33.

11 Tonolo G, Soro A, Madeddu P, et al. Effect of chronic intracerebroventricular dexamethasone on blood pressure in normotensive rats. Am f Physiol 1993;264:E843-7.

12 Melby JC, Dale SL, Holbrook M, et al. 19-Norcorticosteroids in health, in hypertensive states in humans including 17 alpha-hydroxylase deficiency and in the spontaneously

13 Mulatero P, Panarelli M, Schiavone D, et al. Impaired cortisol binding to glucocorticoid receptors in hypertensive patients. Hypertension 1997;30:1274-8.

14 Vingerhoeds AC, Thijssen JH, Schwarz F. Spontaneous hypercortisolism without Cushing's syndrome. I Clin Endocrinol Metab 1976;43:1128-33.

15 Chrousos GP, Vingerhoeds AC, Brandon D, et al. Primary cortisol resistance in man. A glucocorticoid receptormediated disease. 7 Clin Invest 1982;69:1261-9.

16 Griffing GT, Melby JC, Holbrook M, et al. Elevated 18 hydroxycorticosterone in inbred salt sensitive rats. Clin Exp Hypertens 1991;13:371-82.

17 Chrousos GP, Vingerhoeds AC, Loriaux DL, et al. Primary cortisol resistance: a family study. 7 Clin Endocrinol Metab 1983;56:1243-5.

18 Liddle GW, Bledsoe T, Coppage WS. A familial renal disorder simulating primary aldosteronism but with negligible der simulating primary aldosteronism but with negligible
aldosterone secretion. Trans Assoc Am Physicians 1963;76: aldosteron $199-213$.

19 Ulick S, Levine LS, Gunczler P, et al. A syndrome of apparent mineralocorticoid excess associated with defects in the peripheral metabolism of cortisol. F Clin Endocrinol Metab 1979;49:757-64.

20 Kirschbaum C, Wust S, Hellhammer D. Consistent sex differences in cortisol response to psychological stress. Psychosom Med 1992;54:648-57.

21 Roelfsema F, van den Berg G, Frolich M, et al. Sex-dependent alteration in cortisol response to endogenous adrenocorticotropin. F Clin Endocrinol Metab 1993;77:234-40.

22 Pickering TG. Blood pressure monitoring outside the office for the evaluation of patients with resistant hypertension. Hypertension 1988;11 (suppl II):II-96-100.

23 Mancia G, Parati G, Pomidossi G, et al. Validity and usefulness of non invasive ambulatory blood pressure monitoring. F Hypertens $1985 ; 3$ (suppl 2):S5-11.

24 Pickering TG, Harshfield GA, Kleinert HD, et al. Blood pressure during normal daily activities, sleep and exercise. pressure during normal dail
$\mathfrak{f} A M A$ 1982;247:992-6.

25 Hoegholm A, Kristensen KS, Bang LE, et al. Left ventricular mass and geometry in patients with established hypertension and white-coat hypertension. Am $\mathcal{F}$ Hypertens 1993;6:282-6

26 White WB, Schulmen P, McCabe EJ, et al. Average daily blood pressure, not office pressure, determines cardiac function in patients with hypertension. $\mathcal{F} A M A 1989 ; 261: 873-7$.

27 Perloff D, Sokolow M, Cowan RM, et al. Prognostic value of ambulatory blood pressure measurements: further analysis. f Hypertens 1989;7(suppl 3):S3-10.

28 Verdecchia P, Porcellati C, Schillaci G, et al. Ambulatory blood pressure: an independent predictor of prognosis in essential hypertension. Hypertension 1994;24:793-801.

29 Frattola A, Parati G, Cuspidi C, et al. Prognostic value of 24-hour blood pressure variability. $\mathcal{F}$ Hypertens 1993;11: 1133-8.

30 Clark S, Fowlie S, Coats A, et al. Ambulatory blood pressure monitoring: validation of the accuracy and reliability of the TM-2420 according to the AAMI recommendations. $f$ TM-2420 according to the AA
Hum Hypertension 1991;5:77-82.

31 Shackleton CHL, Honour JW. Simultaneous estimation of urinary steroids by semi-automated gas chromatography. 
Investigation of neo-natal infants and children with abnormal steroid synthesis. Clin Chim Acta 1976;69:267-83.

32 Honour JW. Steroid profiling. Ann Clin Biochem 1997;34: $32-44$

33 Soranno D, Prasad V, David R, et al. Hypertension and virilization caused by a unique desoxycorticosterone- and androgen-secreting adrenal adenoma. F Pediatr Endocrinol Metab 1999;12:215-20.

34 Peter M, Sippell WG, Wernze H. Diagnosis and treatmen of 17-hydroxylase deficiency. 7 Steroid Biochem Mol Biol 1993;45:107-16.

35 Stratakis CA, Rennert OM. Congenital adrenal hyperplasia: molecular genetics and alternative approaches to treatment. Crit Rev Clin Lab Sci 1999;36:329-63.

36 Palermo M, Shackleton CHL, Mantero F, et al. Urinary free cortisone and the assessment of $11 \beta$-hydroxysteroid dehydrogenase activity in man. Clin Endocrinol 1996;45:605-11.

37 Morineau G, Marc J, Boudi A, et al. Genetic, biochemical, and clinical studies of patients with A328V or R213C mutations in $11 \beta$-HSD2 causing apparent mineralocorticoid excess. Hypertension 1999;34:435-41.

38 Gomez-Sanchez CE, Montgomery M, Ganguly A, et al. Elevated urinary excretion of 18-oxocortisol in glucocorticoid suppressible aldosteronism. f Clin Endocrinol Metab 1984;59:1022-6.

39 Lifton RP, Dluhy RG, Powers M, et al. A chimaeric 11 betahydroxylase/aldosterone synthase gene causes glucocorticoid-remediable aldosteronism and human hypertension. Nature 1992;355:262-5.

40 Lifton RP, Dluhy RG, Powers $M$, et al. Hereditary hypertension, caused by chimaeric gene duplications and ectopic expression of aldosterone synthase. Nat Genet 1992;2:66-74.

41 Jeunemaitre X, Soubrier F, Kotelevtsev YV, et al. Molecular basis of human hypertension: role of angiotensinogen. Cell 1992;71:169-80.

42 Hopkins PN, Lifton RP, Hollenberg NK, et al. Blunted renal vascular response to angiotensin II is associated with a common variant of the angiotensinogen gene and obesity. 7 Hypertens 1997;14:199-207.

43 Shimkets RA, Warnock DG, Bositis CM, et al. Liddles's syndrome: heritable human hypertension caused by mutations in the $B$ subunit of the epithelial sodium channel. Cell 1994;79:407-14

44 Hansson JH, Nelson-Williams C, Suzuki H, et al. Hypertension caused by a truncated epithelial sodium channel gamma subunit: genetic heterogeneity of Liddle's syngamma subunit: genetic heterog
drome. Nat Genet 1995;11:82.

45 Hansson JH, Schild L, Lu Y, et al. A denovo missense mutation of the beta sub unit of the epithelial sodium channel causes hypertension and Liddle's syndrome and identifies a proline-rich segment of the protein critical for regulation of channel activity. Proc Natl Acad Sci USA 1995;92:11495-9.

46 Tamura H, Schild L, Enomoto N, et al. Liddle's disease caused by a missense mutation of beta subunit of the epithelial sodium channel gene. f Clin Invest 1996;97: 1780-4.

47 Shamim W, Bakhai A, Yousufuddin M, et al. Increased urinary cortisol and androgen metabolites in a young female with hypertension: partial glucocorticoid resistance syndrome. Cardiology 2000;93:131-2

48 Clore J, Schoolwerth A, Watlington CO. When is cortisol a mineralocorticoid? Kidney Int 1992;42:1297-308.

49 Vecsei P, Frank K, Haack D, et al. Primary glucocorticoid receptor defect with likely familial involvement. Cancer Res 1989;49:2220-1S

50 Lamberts SW, Koper JW, Biemond P, et al. Cortisol receptor resistance: the variability of its clinical presentation and response to treatment. $\mathcal{F}$ Clin Endocrinol Metab 1992;74: response

51 Munck A, Guyre PM. Glucocorticoid physiology, pharmacology and stress. In: Chrousos GP, Loriaux DL, Lipsett $\mathrm{MB}$, eds. Steroid hormone resistance: mechanisms and clinical aspects. Advances in experimental medicine and biology. New York: Plenum Press, 1986:81-96.

52 Chrousos GP. Syndromes of glucocorticoid resistance. Ann Intern Med 1993;119:1113-24.

53 Arai K, Chrousos GP. Syndromes of glucocorticoid and mineralocorticoid resistance. Steroids 1995;60:173-9.

\section{IMAGES IN CARDIOLOGY}

\section{Tricuspid valvectomy following tricuspid valve endocarditis on an intravenous drug addict}

A 50 year old man was originally referred in 1983 with a nine week history of multiple complaints of headache, backache, profuse night sweats with rigors, anorexia, and general malaise. He was a registered intravenous drug abuser for many years, and had been recently prescribed methadone. On admission, he had a temperature of $38^{\circ} \mathrm{C}$ and a maculopapular rash over his arms and legs. He was jaundiced and anaemic with a haemoglobin concentration of $7.2 \mathrm{~g} / \mathrm{dl} \quad(4.47 \mathrm{mmol} / \mathrm{l})$. His jugular venous pressure was raised at $4 \mathrm{~cm}$ above the clavicle with a prominent $\mathrm{V}$ wave. On auscultation the patient had a pansystolic murmur at the left sternal edge which was accentuated on inspiration. An echocardiogram showed massive vegetations on the tricuspid valve with severe tricuspid regurgitation. The diagnosis of infective endocarditis was made and confirmed with blood cultures positive for Staphylococcus aureus septicaemia. In November 1983 the patient underwent total valvectomy without insertion of an artificial valve because of the potential for further infections while he continued his rehabilitation. In 1985 he stopped all intravenous drug use. He remained well in New York Heart Association functional class I until 1997 when

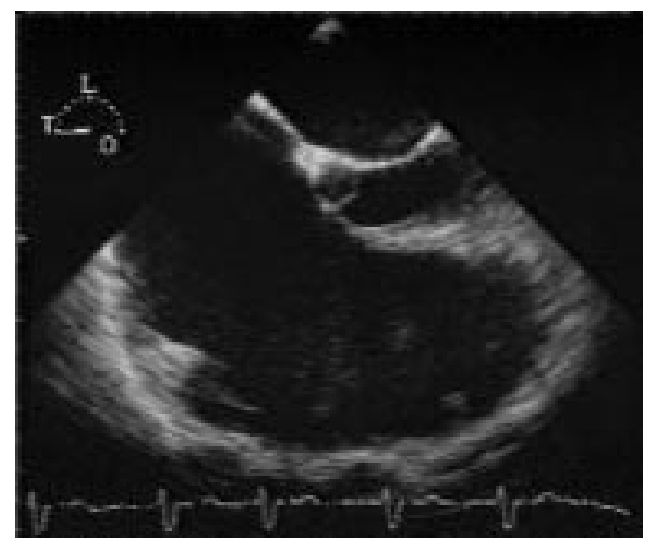

he underwent cardioversion for atrial fibrillation. Despite an early success, the patient remained in controlled atrial fibrillation and is now under consideration for a tricuspid valve replacement.

The figure shows a transoesophageal view of the right ventricular inflow tract, where no tricuspid valve can be seen.

PETROS NIHOYANNOPOULOS petros@ic.ac.uk 